\title{
Seeking genetic determinants of selected metabolic disorders in women aged 45-60
}

\author{
Małgorzata Szkup ${ }^{1, A-F \oplus}{ }^{\oplus}$ Jacek Brodowski ${ }^{2, B, F}{ }^{1}$, Anna Jurczak ${ }^{3, B, F}{ }^{\circ}$, Marzanna Stanisławska $^{1, B, F}$, \\ Elżbieta Grochans ${ }^{1, \mathrm{E}, \mathrm{F} \odot}$
}

\author{
${ }^{1}$ Department of Nursing, Pomeranian Medical University, Szczecin, Poland \\ 2 Primary Care Department, Pomeranian Medical University, Szczecin, Poland \\ ${ }^{3}$ Department of Clinical Nursing, Pomeranian Medical University, Szczecin, Poland \\ A - Research concept and design, B - Collection and/or assembly of data, C - Data analysis and interpretation, \\ $D$ - Writing the article, E - Critical revision of the article, F - Final approval of article
}

\begin{abstract}
Szkup M, Brodowski J, Jurczak A, Stanisławska M, Grochans E. Seeking genetic determinants of selected metabolic disorders in women aged 45-60. Ann Agric Environ Med. 2020; 27(3): 407-412. doi: 10.26444/aaem/112579
\end{abstract}

\begin{abstract}
Introduction and objective. The biochemical and anthropometric consequences of metabolic disorders exert an enormous effect on the functioning of people worldwide. The aim of this study is to assess relationships between biochemical and anthropometric parameters associated with metabolic syndrome, and the presence of the PPAR- $\gamma$ rs1801282, the FTO rs9939609, and the MC4R rs17782313 polymorphisms in women aged 45-60.

Materials and method. The study included 425 women, aged $45-59$ years, from the general population of the West Pomeranian Province in north-west Poland. The research procedure involved a structured interview, anthropometric and blood pressure measurements, biochemical analysis of serum, and genetic analysis.

Results. The carriers of the A/A genotype of the FTO polymorphism had higher LDL levels than their counterparts with the $T / T$ genotype $(p=0.01)$. The carriers of the T/T genotype of the MC4R polymorphism had lower non-HDL levels than those with the $C / C$ and $C / T$ genotypes $(p=0.019)$. Weight was related to the $C / C$ and the $C / G+G / G$ genotypes of the $P P A R-\gamma$ gene polymorphism $(p=0.046)$. The model of inheritance for the $M C 4 R$ polymorphism had a significant effect on TG ( $p=0.039)$ and non-HDL $(p=0.05)$ levels.

Conclusions. The genotypes analyzed in the study had only a slight direct effect on the biochemical and anthropometric abnormalities typical of metabolic disorders. Nonetheless, the risk alleles (A allele of the FTO rs9939609 and the C allele of the MC4R rs17782313) were found to be related to lipid metabolism disorders in 45-60-year-old women.
\end{abstract}

\section{Key words}

Genes, Metabolic Syndrome X, PPAR gamma

\section{INTRODUCTION}

Metabolic disorders - manifested as dyslipidaemia, carbohydrate metabolism disorders, an increased risk of cardiovascular disease, hypertension, and overweight are closely related to each other, and their incidence is growing significantly worldwide [1]. Aside from the undeniable influence of lifestyle, and such its components as physical activity, smoking, and the quality and quantity of food intake, the development of metabolic disorders may also be determined by genetic factors. Therefore, this study attempts to assess relationships between metabolic abnormalities and the polymorphisms in three genes: PPAR- $\gamma, F T O$ and $M C 4 R$, the polymorphic forms of which are suspected of affecting the occurrence of predisposition to disorders associated with the metabolic syndrome and its components.

Single-nucleotide polymorphisms (SNPs) help in explaining the nature of differences between individuals in the human population [2]. The peroxisome proliferator-activated receptor gamma $(P P A R-\gamma)$ gene is one of the factors that can be regarded as essential for understanding individual susceptibility to metabolic disorders. In 1997, an alanine for proline substitution at codon 12 in the PPAR- $\gamma 2$ gene - resulting in the Pro12Ala

Address for correspondence: Anna Jurczak; Żołnierska 48, 71-210 Szczecin, Poland E-mail: anna.jurczak@pum.edu.pl

Received: 01.08.2019; accepted: 25.09.2019; first published: 16.10.2019 (rs1801282) polymorphism - was detected [3]. This substitution can cause a conformational change within the protein, thus affecting its activity [4]. PPAR- $\gamma$ is a cell nuclear receptor. Its expression is observed almost exclusively in adipose tissue, and is mainly responsible for lipid metabolism, adipocyte differentiation, and sensitivity to insulin [5]. Polymorphic forms of the PPAR- $\gamma$ gene are supposed to play a key role in the development of weight disorders [6], and energy balance regulation [5]. They are also regarded as potentially promoting disorders of carbohydrate and lipid metabolism [7].

Another possible contributor to metabolic disorders (especially obesity, type 2 diabetes, and insulin resistance) is the fat mass and obesity-associated (FTO) gene located on the 16q12.2 chromosome $[8,9]$. Frayling et al. noticed that a relatively large amount of the FTO protein ubiquitously expressed in various tissues - can be found in the hypothalamus and pancreatic islets [10], and it is therefore believed to affect energy balance, the central nervous system [8], and adipose tissue at a peripheral level [11]. In 2007, FTO was described in genome-wide association studies (GWAS) as an obesity-related gene in the Caucasian race [10].

One more genetic factor that substantially contributes to obesity - thus predisposing to carbohydrate metabolism disorders and type 2 diabetes - is the melanocortin- 4 receptor (MC4R) rs17782313 polymorphism [12]. It is considered to play an important part in the regulation of food intake, and maintenance of long-term energy homeostasis [13]. 


\section{OBJECTIVES}

The aim of this study was to analyze relationships between the PPAR $\gamma$ rs1801282, the FTO rs9939609, and the $M C 4 R$ rs17782313 polymorphisms and biochemical and anthropometric parameters, as well as health functioning associated with the occurrence of metabolic disorders in 45-60-year-old women.

\section{MATERIALS AND METHOD}

Women were recruited who represented the general population of the West Pomeranian Province in northwest Poland). The size of the study sample was established on the basis of statistical data concerning the size of the population of 45-59-year old women in the West Pomeranian Province in 2015 [14]. The confidence level was set at 95\%, the maximum error at $5 \%$, and estimated fraction size at 0.5 . The group was extended by $10 \%$ to make up for a possible dropout. The total number of women qualified for the study was 425. The inclusion criteria were: female gender, age between 45-60 years, deliberate written consent for taking part in the research, and residence in the West Pomeranian Province. The criteria for temporary exclusion from the study were: a current active inflammatory state of the body (verified by the C-reactive protein [CRP] measurement), as well as oncological and psychiatric disorders.

The results were obtained as part of a larger investigation to analyze the influence of a wide array of biological, social, and psychological factors on women's functioning in the peri- and postmenopausal periods. The authors of this study recommend reading their papers on studies of same study sample, aimed at establishing the association between different MetS-related abnormalities and gene polymorphisms [15], and to assess relationships between MetS and the presence of the FTO rs9939609, the MC4R rs17782313, and the PPAR- $\gamma$ rs1801282 polymorphisms in 45-60-year-old women [16].

The presented study was conducted in accordance with the Declaration of Helsinki, and the protocol approved by the Bioethical Commission of Pomeranian Medical University in Szczecin, Permission Nos. KB-0012/181/13 and KB0012/104/11.

Each patient received written information about the purpose and course of the study, as well as the possibility to resign at any stage of the research procedure without sating reasons.

The research procedure was divided into four stages, namely: a structured interview, anthropometric and blood pressure measurements, biochemical analysis of serum, and genetic analysis.

The purpose of the structured interview was to obtain data from each patient concerning her health status. The women provided information about menstruating (yes/no), smoking (yes/no), alcohol consumption (yes: more than $140 \mathrm{~g}$ of $100 \%$ alcohol per week / no: abstinence, or less than $140 \mathrm{~g}$ of $100 \%$ alcohol per week), diagnosed coronary thrombosis (yes/no), type 2 diabetes (yes/no), and hyperlipidaemia (yes/no). During the interview, the patients received all information necessary to fully understand the questions and give truthful answers.

The next stage of the study involved anthropometric and blood pressure measurements. Each patient was weighed and measured on an empty stomach, after urination, wearing light clothes and without shoes. The measurements were performed using an electronic scale with a measuring rod. Both waist circumference (WC) and hip circumference (HC) were measured in a standing position: WC - between the lower rib margin and the upper margin of the iliac crest, at the end of a gentle exhalation; and $\mathrm{HC}$ - at the level of the maximum protrusion of the gluteus muscles. $\mathrm{WC} \leq 80 \mathrm{~cm}$ was assumed as normal. Based on the data obtained, the body mass index (BMI) and waist - hip ratio (WHR) were calculated. BMI within the range $18.5-24.9 \mathrm{~kg} / \mathrm{m}^{2}$ was regarded as normal, BMI within the range $25.0-29.9 \mathrm{~kg} / \mathrm{m}^{2}$ denoted overweight, and BMI $\geq 30 \mathrm{~kg} / \mathrm{m}^{2}$ - obesity. A WHR was calculated through dividing WC by $\mathrm{HC}$; values $<0.8$ were assumed to indicate a gynoid type of adipose tissue distribution, and values $\geq 0.8$ suggested an android type of distribution. Systolic (sBP) and diastolic (dBP) blood pressure was assessed in a sitting position using a manual manometer. The cuff of the manometer was selected for the arm circumference and wrapped snugly around the patient's right upper arm at the heart level. The patients were allowed at least a five-minute rest before the measurement.

As the next step, venous blood samples were taken from each patient on an empty stomach (minimum 8 hours from the last meal), using the Vacutainer system. The blood was collected in accordance with the relevant rules and procedures. The following biochemical parameters were determined in serum: insulin (normal range: 2.6-24.9uIU/mL), total cholesterol (TCh) (normal range: $115-190 \mathrm{mg} / \mathrm{dl}$ ), high density lipoprotein (HDL) (normal level $>50 \mathrm{mg} / \mathrm{dl}$ ), low-density lipoprotein (LDL) (normal level < $115 \mathrm{mg} / \mathrm{dl}$ ), triglycerides (TG) (normal level < $150 \mathrm{mg} / \mathrm{dl}$ ), and glucose (normal range: 60-99 mg/dl). Additionally calculated, on the basis of the results, were non-HDL=TCh $-\mathrm{HDL}$ (normal level $<145 \mathrm{mg} / \mathrm{dl}$ ), and the homeostasis model of assessment of insulin resistance (HOMA-IR) index=serum glucose level $(\mathrm{mg} / \mathrm{dl}) \mathrm{x}$ insulin level $(\mu \mathrm{IU} / \mathrm{ml})$ divided by 405 (normal level $\leq 2.5$ ).

The patients were categorized as having metabolic syndrome (MetS) if they had at least three out of five abnormalities: $\geq 100 \mathrm{mg} / \mathrm{dl}$ or treatment for hyperglycaemia, triglycerides $\geq 150 \mathrm{mg} / \mathrm{dl}$ or related pharmacotherapy, HDL cholesterol $<50 \mathrm{mg} / \mathrm{dl}$ or related pharmacotherapy, and elevated BP systolic and/or diastolic blood pressure (sBP $\geq 130$ and/or $\mathrm{dBP} \geq 85 \mathrm{mmHg}$ ) or related pharmacotherapy [17].

In the remaining part of the biological material, genotyping was performed of the PPAR- $\gamma \operatorname{rs1801282}(\mathrm{C}>\mathrm{G})$, FTO rs9939609 (T>A), and MC4R rs17782313 (T>C) polymorphisms. Genomic DNA was isolated from whole blood in accordance with standard salting procedures [18]. All genotyping was based on the real-time fluorescence resonance energy transfer (FRET) performed using the Light Cycler System 1.0 (Roche Diagnostic, Poland). The following were applied for the polymorphism in the gene: polymerase chain reaction (PCR) was performed with 50 ng DNA in a total volume of $20 \mathrm{ml}$ containing $2 \mathrm{ml}$ reaction mix, $0.5 \mathrm{mM}$ of each primer, $0.2 \mathrm{mM}$ of each hybridization probe and $2 \mathrm{mM} \mathrm{MgCl}$ according to the manufacturer's instructions for 35 cycles of denaturation $\left(95^{\circ} \mathrm{C}\right.$ for $\left.10 \mathrm{~min}\right)$, annealing $60^{\circ} \mathrm{C}$ for 10 seconds) and extension $\left(72^{\circ} \mathrm{C}\right.$ for 15 seconds). After amplification, a melting curve was generated by holding the reaction at $40^{\circ} \mathrm{C}$ for 20 seconds and then heating slowly to $85^{\circ} \mathrm{C}$. The fluorescence signal was plotted against temperature to give melting curves for each sample. 
The polymorphisms were determined on the basis of analysis of the melting curves. In the PPAR- $\gamma$ rs 1801282 $(\mathrm{C}>\mathrm{G})$ polymorphism, peaks were obtained at $53.14^{\circ} \mathrm{C}$ for the $\mathrm{G}$ allele and at $62.12^{\circ} \mathrm{C}$ for the $\mathrm{C}$ allele. In the FTO rs 9939609 (T>A) polymorphism, peaks were obtained at $58.02^{\circ} \mathrm{C}$ for the A allele and at $63.08^{\circ} \mathrm{C}$ for the T allele. The fluorescence signal was plotted against temperature to give melting curves for each sample. Peaks were obtained at $49.5^{\circ} \mathrm{C}$ for the T allele and at $58.23^{\circ} \mathrm{C}$ for the $\mathrm{C}$ allele.

Statistical analysis was performed using the $\mathrm{R}$ package (R Foundation for Statistical Computing, Vienna, Austria). Continuous variables were described by minimum and maximum values, the mean \pm standard deviation, the median, as well as lower and upper quartiles. The number $(\mathrm{N})$ and per cent values were presented in the description of categorical variables. The chi-square test was used to analyze the distribution of genotypes/alleles. To determine associations between the genotypes and the biochemical and anthropometric indices, analysis of variance (ANOVA) was conducted. Logistic regression analysis was used to estimate odds ratios (OR) for the relationships between the genes PPAR- $\gamma$ rs1801282, the FTO rs9939609, and the MC4R rs17782313 polymorphisms and the biochemical,las well as anthropometric parameters. A 95\% confidence interval was assumed. Statistical significance was set at 0.05 .

\section{RESULTS}

The mean age of the participants was $54.3 \pm 4.2$ years. $16.47 \%$ of them were still menstruating, $20.23 \%$ smoked cigarettes, and $15.29 \%$ admitted to alcohol consumption. The women suffered from the following chronic diseases: $38.35 \%$ had a diagnosis of MetS, $14.35 \%$ had elevated serum cholesterol levels, $13.17 \%$ had type 2 diabetes, and $4.23 \%$ had coronary thrombosis. Weight disorders also constituted a serious problem: $38.12 \%$ of the women were overweight, and $29.65 \%$ were obese. Results of biochemical analysis that were noteworthy were the mean levels of TCh $(218.4 \pm 43.2 \mathrm{mg} / \mathrm{dL})$, LDL $(132.6 \pm 39.4 \mathrm{mg} / \mathrm{Dl})$ and non-HDL $(155.6 \pm 43.8 \mathrm{mg} / \mathrm{dL})$, which were too high, even when measured for the whole study sample. The mean results of some anthropometric measurements also deviated from normal values: $\mathrm{BMI}-27.9 \pm 5.2 \mathrm{~kg} / \mathrm{m}^{2}, \mathrm{WC}-87.7 \pm 10.7 \mathrm{~cm}$, and WHR indicated an android body type (Tab. 1).

Table 2 shows the distribution of genotypes and alleles of the PPAR- $y$ rs1801282, FTO rs9939609, and MC4R rs17782313 polymorphisms. Only the distribution of the alleles of the FTO rs9939609 polymorphism diverged from the Hardy-Weinberg distribution ( $p>0.05)$. In other cases, no divergence was observed (Tab. 2).

The analysis of genetic and biochemical parameters demonstrated statistically significant relationships between serum LDL levels and the presence of particular genotype combinations of the FTO gene polymorphism $(\mathrm{p}=0.01)$. Patients with the A/A genotype had significantly higher LDL levels than their counterparts with the T/T genotype. The same was observed for TCh $(\mathrm{p}=0.059)$ and TG $(\mathrm{p}=0.067)$.

The carriers of the T/T genotype of the $M C 4 R$ gene polymorphism had significantly lower non-HDL levels than those with the $\mathrm{C} / \mathrm{C}$ and $\mathrm{C} / \mathrm{T}$ genotypes $(\mathrm{p}=0.019)$. A similar relationship was observed for TG $(\mathrm{p}=0.05)$. Analysis of other biochemical and anthropometric variables, as well as blood pressure, did not reveal any significant associations with the
Table 1. Characteristics of the study sample with regard to biochemical and anthropometric parameters, as well as health functioning $(\mathrm{N}=425)$

\begin{tabular}{|c|c|c|c|c|}
\hline Continuous variables & $\mathrm{x}_{\min }$ & $\mathrm{x}_{\max }$ & $\bar{x} \pm \mathrm{SD}$ & $\operatorname{Me}\left(Q_{1}-Q_{3}\right)$ \\
\hline Insulin [ulU/ml]* & 2.20 & 40.20 & $11.14 \pm 6.65$ & $9.35(7.09-12.72)$ \\
\hline Glucose [mg/dl] & 63.0 & 348.0 & $95.0 \pm 30.2$ & $88.0(80.0-99.0)$ \\
\hline HOMA-IR* & 0.40 & 32.39 & $2.84 \pm 2.85$ & $2.09(1.47-3.08)$ \\
\hline $\mathrm{TCh}[\mathrm{mg} / \mathrm{dl}]$ & 94.0 & 359.0 & $218.4 \pm 43.2$ & $216(191.0-242.0)$ \\
\hline $\mathrm{LDL}[\mathrm{mg} / \mathrm{dl}]^{*}$ & 38.2 & 283.0 & $132.6 \pm 39.4$ & $134.0(107.0-159.0)$ \\
\hline $\mathrm{HDL}[\mathrm{mg} / \mathrm{dll}]^{*}$ & 22.0 & 143.0 & $63.0 \pm 17.0$ & $61.0(50.0-73.0)$ \\
\hline $\mathrm{TG}[\mathrm{mg} / \mathrm{dl}]$ & 28.0 & 445.0 & $117.7 \pm 64.4$ & $100.0(73.0-141.0)$ \\
\hline non-HDL [mg/dl] & 52.0 & 311.0 & $155.6 \pm 43.8$ & $153.0(125.0-184.0)$ \\
\hline Body weight $[\mathrm{kg}]^{*}$ & 43.8 & 123.4 & $73.5 \pm 13.4$ & $71.4(64.0-82.0)$ \\
\hline BMI $\left[\mathrm{kg} / \mathrm{m}^{2}\right]$ & 17.7 & 53.7 & $27.9 \pm 5.2$ & $27.0(24.2-30.9)$ \\
\hline $\mathrm{HC}[\mathrm{cm}]$ & 68.0 & 149.0 & $102.6 \pm 8.5$ & $101.4(96.6-106.8)$ \\
\hline$W C[\mathrm{~cm}]$ & 62.9 & 126.0 & $87.7 \pm 10.7$ & $86.0(80.0-94.3)$ \\
\hline WHR [j] & 0.65 & 1.13 & $0.85 \pm 0.1$ & $0.84(0.81-0.90)$ \\
\hline $\mathrm{sBP}[\mathrm{mmHg}]$ & 90.0 & 180.0 & $127.3 \pm 15.8$ & $130.0(120.0-140.0)$ \\
\hline $\mathrm{dBP}[\mathrm{mmHg}]$ & 50.0 & 120.0 & $78.8 \pm 10.3$ & $80.0(70.0-85.0)$ \\
\hline Categorical variables & \multicolumn{3}{|c|}{$\mathrm{N}$} & $\%$ \\
\hline Menstruating & \multicolumn{3}{|c|}{70} & $16.47 \%$ \\
\hline Smoking & \multicolumn{3}{|c|}{86} & $20.23 \%$ \\
\hline Drinking alcohol & \multicolumn{3}{|c|}{65} & $15.29 \%$ \\
\hline With coronary thrombosis & \multicolumn{3}{|c|}{18} & $4.23 \%$ \\
\hline With type 2 diabetes & \multicolumn{3}{|c|}{56} & $13.17 \%$ \\
\hline With hyperlipidemia & \multicolumn{3}{|c|}{61} & $14.35 \%$ \\
\hline With MetS & \multicolumn{3}{|c|}{163} & $38.35 \%$ \\
\hline Overweight & \multicolumn{3}{|c|}{162} & $38.12 \%$ \\
\hline Obesity & \multicolumn{3}{|c|}{126} & $29.65 \%$ \\
\hline
\end{tabular}

*deviating data cases were removed

$\mathrm{X}_{\min }-\mathrm{X}_{\max }-$ minimum-maximum; $\bar{x} \pm \mathrm{SD}-$ mean \pm standard deviation; $\mathrm{Me}-$ median; $\mathrm{Q}_{1}-\mathrm{Q}_{3}-$ lower quartiles - upper quartile; $\mathrm{N}$ - number of cases

Table 2. Distribution of the genotypes and alleles of the PPAR $r$ rs1801282, the FTO rs9939609, and the MC4R rs17782313 polymorphisms in the study sample $(\mathrm{N}=425)$

\begin{tabular}{|c|c|c|c|}
\hline SNP & Genotype/allele & $\mathrm{N}=425 / 850(\%)$ & p-value \\
\hline \multirow[t]{5}{*}{ PPARy rs1801282 } & $\mathrm{C} / \mathrm{C}$ & 294 (69.18\%) & \multirow{3}{*}{$p=0.320$} \\
\hline & $C / G$ & 107 (25.18\%) & \\
\hline & $\mathrm{G} / \mathrm{G}$ & $24(5.66 \%)$ & \\
\hline & C & 695 (81.76\%) & \multirow{2}{*}{$p=0.461$} \\
\hline & G & 155 (18.24\%) & \\
\hline \multirow[t]{5}{*}{ FTO rs9939609 } & $A / A$ & $83(19.53 \%)$ & \multirow{3}{*}{$p=0.056$} \\
\hline & $\mathrm{A} / \mathrm{T}$ & $198(46.59 \%)$ & \\
\hline & $T / T$ & 144 (33.88\%) & \\
\hline & A & 364 (42.82\%) & \multirow{2}{*}{$\mathrm{p}<0.05$} \\
\hline & $\mathrm{T}$ & $486(57.18 \%)$ & \\
\hline \multirow[t]{5}{*}{ MC4R rs 17782313} & $\mathrm{C} / \mathrm{C}$ & $10(2.35 \%)$ & \multirow{3}{*}{$p=0.363$} \\
\hline & $\mathrm{C} / \mathrm{T}$ & $141(33.18 \%)$ & \\
\hline & $\mathrm{T} / \mathrm{T}$ & $274(64.47 \%)$ & \\
\hline & C & 161 (18.94\%) & \multirow{2}{*}{$p=0.909$} \\
\hline & $\mathrm{T}$ & 689 (81.06\%) & \\
\hline
\end{tabular}

SNP - single-nucleotide polymorphism; $\mathrm{N}$ - number of cases; $\mathrm{p}$ - significance level

genotypes of the above-mentioned polymorphism or the genotypes of the PPAR- $\gamma$ polymorphism (Tab. 3). 
Table 3. Analysis of relationships between biochemical and anthropometric parameters and the genotypes of PPARy rs1801282, FTO rs9939609, and MC4R rs17782313 polymorphisms

\begin{tabular}{|c|c|c|c|c|c|c|c|c|c|c|c|c|}
\hline \multirow{2}{*}{$\begin{array}{l}\text { Continuous } \\
\text { variables }\end{array}$} & \multicolumn{4}{|c|}{ PPARY } & \multicolumn{4}{|c|}{ FTO } & \multicolumn{4}{|c|}{ MC4R } \\
\hline & $\mathrm{C} / \mathrm{C}$ & $C / G$ & $\mathrm{G} / \mathrm{G}$ & $\mathrm{p}$ & $\mathrm{A} / \mathrm{A}$ & $\mathrm{A} / \mathrm{T}$ & $T / T$ & $p$ & $\mathrm{C} / \mathrm{C}$ & $\mathrm{C} / \mathrm{T}$ & $T / T$ & $p$ \\
\hline Insulin $[\mathrm{ulU} / \mathrm{ml}]^{*}$ & $11.4 \pm 6.9$ & $10.9 \pm 6.4$ & $9.8 \pm 3.8$ & 0.489 & $11.5 \pm 6.9$ & $11.2 \pm 6.5$ & $10.9 \pm 6.7$ & 0.833 & $14 \pm 11.5$ & $11 \pm 6$ & $11.1 \pm 6.8$ & 0.375 \\
\hline HOMA-IR* & $3 \pm 3.2$ & $2.6 \pm 2$ & $2.2 \pm 1$ & 0.323 & $2.8 \pm 2.4$ & $2.7 \pm 2$ & $3 \pm 3.9$ & 0.568 & $3.6 \pm 3.5$ & $2.7 \pm 2.5$ & $2.9 \pm 3$ & 0.593 \\
\hline $\mathrm{TCh}[\mathrm{mg} / \mathrm{dl}]$ & $218.1 \pm 42.7$ & $219.2 \pm 44.8$ & $222.2 \pm 45$ & 0.895 & $221 \pm 49.4$ & $222.4 \pm 40$ & $211.5 \pm 43.2$ & 0.059 & $204.9 \pm 45.8$ & $224.6 \pm 48.4$ & $215.8 \pm 40$ & 0.089 \\
\hline $\mathrm{HDL}[\mathrm{mg} / \mathrm{dl}]^{*}$ & $63.5 \pm 17.1$ & $60.4 \pm 17$ & $67 \pm 12.9$ & 0.127 & $61 \pm 16.2$ & $63.8 \pm 18.4$ & $63 \pm 15.2$ & 0.453 & $70.4 \pm 30.9$ & $61.8 \pm 15.6$ & $63.3 \pm 16.9$ & 0.263 \\
\hline $\mathrm{TG}[\mathrm{mg} / \mathrm{dl}]$ & $118.8 \pm 65.3$ & $118.6 \pm 64.3$ & $105.5 \pm 53.3$ & 0.624 & $131.6 \pm 70.3$ & $116.7 \pm 58.5$ & $111.1 \pm 67.7$ & 0.067 & $101.4 \pm 49.1$ & $128.2 \pm 76.2$ & $112.9 \pm 57.4$ & 0.05 \\
\hline non-HDL [mg/dl] & $154.8 \pm 42.6$ & $158.9 \pm 46.7$ & $155.2 \pm 45.1$ & 0.716 & $160 \pm 51.8$ & $158.6 \pm 41.1$ & $149 \pm 42$ & 0.078 & $134.5 \pm 45.6$ & $163.2 \pm 49.1$ & $152.5 \pm 40.3$ & 0.019 \\
\hline Body weight $[\mathrm{kg}]^{*}$ & $74.4 \pm 13.5$ & $71.3 \pm 13.5$ & $72.7 \pm 10.1$ & 0.12 & $74.8 \pm 12.9$ & $73.3 \pm 14.3$ & $73 \pm 12.3$ & 0.612 & $71.7 \pm 16.8$ & $73 \pm 12.2$ & $73.8 \pm 13.9$ & 0.75 \\
\hline $\mathrm{BMI}[\mathrm{kg} / \mathrm{m} 2]$ & $28.3 \pm 5.2$ & $27.3 \pm 5.3$ & $27 \pm 4.5$ & 0.18 & $28.3 \pm 5$ & $27.9 \pm 5.5$ & $27.8 \pm 4.9$ & 0.743 & $28 \pm 9.8$ & $27.6 \pm 4.6$ & $28.1 \pm 5.3$ & 0.643 \\
\hline$W C[\mathrm{~cm}]$ & $88.2 \pm 10.8$ & $86.5 \pm 10.6$ & $87.3 \pm 9$ & 0.362 & $88.8 \pm 9.6$ & $87.8 \pm 11.5$ & $87.1 \pm 10$ & 0.509 & $86.9 \pm 13.8$ & $87.3 \pm 10.2$ & $88 \pm 10.8$ & 0.819 \\
\hline WHR [j] & $0.9 \pm 0.1$ & $0.8 \pm 0.1$ & $0.9 \pm 0.1$ & 0.789 & $0.9 \pm 0.1$ & $0.8 \pm 0.1$ & $0.9 \pm 0.1$ & 0.527 & $0.9 \pm 0.1$ & $0.8 \pm 0.1$ & $0.9 \pm 0.1$ & 0.755 \\
\hline $\mathrm{sBP}[\mathrm{mmHg}]$ & $128.2 \pm 15.5$ & $125.9 \pm 16.8$ & $122.8 \pm 14$ & 0.157 & $129 \pm 17.1$ & $127.5 \pm 16.2$ & $126 \pm 14.3$ & 0.369 & $127 \pm 16.2$ & $127.8 \pm 14.5$ & $127.1 \pm 16.4$ & 0.908 \\
\hline $\mathrm{dBP}[\mathrm{mmHg}]$ & $79.4 \pm 10.2$ & $77.5 \pm 10.8$ & $77.1 \pm 9.4$ & 0.189 & $79.2 \pm 10.1$ & $79.6 \pm 10.3$ & $77.5 \pm 10.5$ & 0.164 & $80 \pm 11.5$ & $79.2 \pm 9.6$ & $78.5 \pm 10.7$ & 0.782 \\
\hline
\end{tabular}

Data are presented as mean \pm standard deviation; $p$ - significance level for analysis of variance (ANOVA)

The last analysis was based on logistic regression with the aim of establishing whether the models of inheritance (overdominant and recessive) were related to blood pressure, or biochemical and anthropometric indicators of metabolic disorders. A statistically significant relationship was demonstrated between weight and the presence of the $\mathrm{C} / \mathrm{C}$ and the $\mathrm{C} / \mathrm{G}+\mathrm{G} / \mathrm{G}$ genotypes of the PPAR- $\gamma$ gene polymorphism $(\mathrm{p}=0.046)$. The carriers of the $\mathrm{C} / \mathrm{G}+\mathrm{G} / \mathrm{G}$ genotypes were at considerably higher risk of increased body weight than those with the $\mathrm{C} / \mathrm{C}$ genotype $(\mathrm{OR}=1.017)$. There were also significant differences in total cholesterol $(\mathrm{p}=0.019)$ and non-
HDL ( $\mathrm{p}=0.026)$ levels between the carriers of the A/A + T/A genotypes of the FTO gene polymorphism and those with the T/T genotype. In both cases, the A/A + T/A genotypes predisposed to elevated cholesterol levels more than other genotypes (TCh: OR=0.994; non-HDL: OR=0.995). The model of inheritance for the MC4R polymorphism had a significant impact on TG $(p=0.039)$ and non-HDL $(p=0.05)$ levels. The $\mathrm{C} / \mathrm{C}+\mathrm{C} / \mathrm{T}$ genotypes predisposed to elevated $\mathrm{TG}$ and non-HDL levels more than the T/T genotype (Tab. 4).

Table 4. Model of logistic regression illustrating the relationships between models of inheritance for genotypes of PPARy rs1801282, FTO rs9939609, and MC4R rs17782313 polymorphisms and biochemical and anthropometric parameters.

\begin{tabular}{|c|c|c|c|c|c|c|c|c|c|}
\hline \multirow[t]{2}{*}{ Continuous variables } & \multicolumn{3}{|c|}{$\begin{array}{c}\text { PPARy } \\
\text { C/C vs. } C / G+G / G\end{array}$} & \multicolumn{3}{|c|}{$\begin{array}{c}\text { FTO } \\
\text { T/T vs. } A / A+T / A\end{array}$} & \multicolumn{3}{|c|}{$\begin{array}{c}\text { MC4R } \\
\text { T/T vs. } C / C+C / T\end{array}$} \\
\hline & OR & $95 \% \mathrm{Cl}$ & $\mathrm{p}$ & OR & $95 \% \mathrm{Cl}$ & $\mathrm{p}$ & OR & $95 \% \mathrm{Cl}$ & $\mathrm{p}$ \\
\hline Insulin [ulU/ml]* & 1.016 & $0.984-1.05$ & 0.327 & 0.992 & $0.962-1.023$ & 0.617 & 0.998 & $0.969-1.029$ & 0.917 \\
\hline Glucose [mg/dl] & 1.005 & $0.997-1.013$ & 0.269 & 1.004 & $0.997-1.01$ & 0.236 & 1.004 & $0.997-1.011$ & 0.301 \\
\hline HOMA-IR* & 1.064 & $0.972-1.163$ & 0.178 & 1.035 & $0.966-1.108$ & 0.331 & 1.011 & $0.942-1.087$ & 0.756 \\
\hline $\mathrm{TCh}[\mathrm{mg} / \mathrm{dl}]$ & 0.999 & $0.994-1.004$ & 0.717 & 0.994 & $0.989-0.999$ & 0.019 & 0.996 & $0.991-1.001$ & 0.09 \\
\hline $\mathrm{LDL}[\mathrm{mg} / \mathrm{dl}]^{*}$ & 1.000 & $0.997-1.004$ & 0.822 & 1.001 & $0.998-1.005$ & 0.439 & 0.997 & $0.994-1.001$ & 0.111 \\
\hline $\mathrm{HDL}[\mathrm{mg} / \mathrm{dll}]^{*}$ & 1.007 & $0.994-1.02$ & 0.282 & 1.000 & $0.988-1.012$ & 0.994 & 1.003 & $0.991-1.015$ & 0.601 \\
\hline $\mathrm{TG}$ [mg/dl] & 1.001 & $0.997-1.004$ & 0.701 & 0.997 & $0.994-1.001$ & 0.135 & 0.997 & $0.994-1.000$ & 0.039 \\
\hline non-HDL [mg/dl] & 0.998 & $0.994-1.003$ & 0.464 & 0.995 & 0.99-0.999 & 0.026 & 0.995 & $0.991-1.000$ & 0.05 \\
\hline Body weight $[\mathrm{kg}]^{*}$ & 1.017 & $1.000-1.033$ & 0.046 & 0.996 & $0.981-1.011$ & 0.621 & 1.005 & $0.99-1.0210$ & 0.482 \\
\hline BMI [kg/m2] & 1.040 & $0.997-1.084$ & 0.068 & 0.991 & $0.953-1.03$ & 0.648 & 1.018 & $0.979-1.059$ & 0.36 \\
\hline $\mathrm{HC}[\mathrm{cm}]$ & 1.018 & $0.993-1.044$ & 0.163 & 0.983 & $0.959-1.007$ & 0.161 & 1.001 & $0.978-1.025$ & 0.941 \\
\hline$W C[\mathrm{~cm}]$ & 1.014 & $0.994-1.035$ & 0.165 & 0.991 & $0.972-1.01$ & 0.354 & 1.006 & $0.987-1.025$ & 0.533 \\
\hline WHR [j] & 2.265 & $0.139-36.932$ & 0.566 & 1.114 & $0.074-16.708$ & 0.938 & 2.213 & $0.151-32.523$ & 0.562 \\
\hline $\mathrm{sBP}[\mathrm{mmHg}]$ & 1.012 & $0.998-1.025$ & 0.089 & 0.992 & $0.979-1.005$ & 0.224 & 0.997 & $0.985-1.010$ & 0.678 \\
\hline $\mathrm{dBP}[\mathrm{mmHg}]$ & 1.019 & $0.999-1.04$ & 0.069 & 0.981 & $0.962-1.001$ & 0.061 & 0.994 & $0.975-1.013$ & 0.51 \\
\hline
\end{tabular}

*deviating data cases were removed

$\mathrm{OR}$ - odds ratio; $\mathrm{Cl}$ - confidence interval; $\mathrm{p}$ - significance level 


\section{DISCUSSION}

The influence of the PPAR- $\gamma$ rs1801282 polymorphism on the parameters indicating metabolic disorders is a dubious issue. The first reports demonstrated the $G$ variant to be typically found in low-weight people, which suggests that it may play a protective role in development of obesity [19]. Some authors discern a connection between the C/G genotype and a lower BMI in populations of both adults [4] and children [20]. According to others, the C/G genotype predisposes to a higher BMI, earlier development of obesity in women, and a larger hip size [21]. Swarbrick et al., however, deny any relationship between the $\mathrm{C} / \mathrm{G}$ genotype and obesity [22]. In the current study, the $\mathrm{C} / \mathrm{G}$ and $\mathrm{G} / \mathrm{G}$ genotypes were found to be accompanied by higher weight than the $\mathrm{C} / \mathrm{C}$ genotype.

Associations between the genotypes of the PPAR- $\gamma$ rs1801282 polymorphism and other biochemical and anthropometric indicators of metabolic disorders have also not been clearly elucidated. Altshuler et al. came to the conclusion that the $\mathrm{C} / \mathrm{G}$ genotype can fulfill a protective function through reducing the risk of type 2 diabetes [23] and increasing insulin sensitivity [4]. This was supported by a study on Asian Indian Sikhs, which strongly suggested a significantly lower risk of type 2 diabetes among carriers of the C/G genotype [24]. Swarbrick et al. did not confirm a relationship between the mutant allele and type 2 diabetes or hypertension. What is interesting, however, is their observation that obese carriers of the G allele considerably more often suffered from lipid metabolism disorders [22]. In the current study, these polymorphism genotypes were notdirectly linked to other parameters of metabolic disorders.

Another polymorphism analyzed in this study was the FTO rs9939609. Numerous studies indicate an association between the A allele and an increased risk of metabolic disorders. A study of 177,330 subjects performed by Qibin et al, revealed that this allele visibly influenced the BMI of all participants, with this effect being stronger for white people than for African-Americans and Asians [25]. Wholegenome association studies conducted on the population of Europe provided evidence for modest associations between polymorphic variants of the FTO gene and type 2 diabetes and obesity. The association between type 2 diabetes and the A allele appeared to be largely mediated by BMI [10, 26]. A study of 38,759 white Europeans, conducted by Frayling et al., revealed an additive association between the rs9939609 and BMI. The minor A allele occurs in the European population with a relatively high frequency (up to $45 \%$ ). Those who were at especially high risk of body weight disorders and type 2 diabetes were the carriers of the homozygous A allele, constituting $16 \%$ of the study sample [10]. In the current study, the A allele was observed in $42.82 \%$, and the A/A genotype in $19.53 \%$ of the participants. Studies on the Han Chinese [27] and oceanic populations (Melanesians, Micronesians, and Polynesians) [28] suggest that the relationship between particular genotypes of the FTO polymorphism and the tendency to develop diabetes and weight disorders, can vary by ethnic group. The frequency of the A allele in the Han Chinese population was considerably lower than in the European population. The FTO variants were not found to be related to BMI, overweight, obesity, WC, or such biochemical parameters as glucose and insulin levels [26]. In the oceanic populations, the connection between the A allele and BMI was not confirmed [28]. Analysis of the Vietnamese showed that type 2 diabetes was related to the presence of the A allele as an obesity-independent risk factor [29]. In the current study, the A/A genotype had a significant effect on the lipid profile, entailing a greater risk of lipid metabolism disorders.

The last tested polymorphism was the MC4R rs17782313. The studies conducted to-date imply that the $\mathrm{C}$ allele may be a risk factor for the development of metabolic disorders. Mutombo et al. demonstrated that the carriers of the T/C + C/C genotypes of the $M C 4 R$ rs17782313 polymorphism had a visibly higher BMI and higher levels of glycated haemoglobin than those with the T/T genotype, even after taking into account such variables as age and gender. Proneness to type 2 diabetes in this group was not linked to a tendency to obesity [12]. A study of the Chinese population, on the other hand, suggested a relationship between the $\mathrm{C} / \mathrm{T}$ genotype of the $M C 4 R$ rs17782313 polymorphism and a higher waist-to-hip ratio, even after multiple testing correction [30]. According to Qi et al., the $\mathrm{C}$ allele of this polymorphism contributes to a higher demand for energy drawn from food and a higher fat intake, thus resulting in a tendency to obesity [31]. It has been calculated that the presence of both copies of the $C$ allele increases BMI by approximately $0.22 \mathrm{~kg} / \mathrm{m}^{2}$ in adults [32]. An increase in body weight may be a factor contributing to type 2 diabetes: the $\mathrm{C}$ allele raises the risk of developing this health problem by $14 \%$, on average. A negative consequence of having the $\mathrm{C}$ allele was particularly visible in the population of women [31]. This study has demonstrated that higher levels of TG and non-HDL are related to the C/T genotype, and that the $\mathrm{C}$ allele substantially increased the risk of lipid metabolism disorders.

\section{CONCLUSIONS}

Particular genotypes of the PPAR- $\gamma$ rs1801282, FTO rs9939609, and MC4R rs17782313 polymorphisms have a slight direct influence on the expression of biochemical and anthropometric abnormalities typical of metabolic disorders in 45-60-year-old women.

The risk alleles (A allele of the FTO rs9939609 polymorphism, and the $\mathrm{C}$ allele of the MC4R rs17782313 polymorphism) are related to lipid metabolism disorders in 45-60-year-old women.

\section{REFERENCES}

1. Matsuo T, Nakata Y, Katayama Y, et al. PPARG genotype accounts for part of individual variation in body weight reduction in response to calorie restriction. Obesity (Silver Spring). 2009; 17(10): 1924-31. DOI: 10.1038/oby.2009.199

2. Bouchard C, Pérusse L. Current status of the human obesity gene map. Obes Res. 1996; 4: 81-90.

3. Yen CJ, Beamer BA, Negri C, et al. Molecular scanning of the human peroxisome proliferator activated receptor gamma (hPPAR gamma) gene in diabetic Caucasians: identification of a Pro12Ala PPAR gamma 2 missense mutation. Biochem Biophys Res Commun. 1997; 241: 270-274. DOI: $10.1006 /$ bbrc.1997.7798.

4. Deeb SS, Fajas L, Nemoto M, et al. A Pro12Ala substitution in PPARgamma2 associated with decreased receptor activity, lower body mass index and improved insulin sensitivity. Nat Genet. 1998; 20: 284-287. DOI: 10.1038/3099.

5. Cecil JE, Watt P, Palmer CN, et al. Energy balance and food intake: the role of PPARgamma gene polymorphisms. Physiol Behav. 2006; 88(3): 227-33. DOI: 10.1016/j.physbeh.2006.05.028. 
6. Rankinen T, Zuberi A, Chagnon YC, et al. The human obesity gene map: the 2005 update. Obesity (Silver Spring). 2006; 14: 529-644. DOI: $10.1038 /$ oby.2006.71

7. Vogels N, Mariman EC, Bouwman FG, et al. Relation of weight maintenance and dietary restraint to peroxisome proliferator-activated receptor gamma2, glucocorticoid receptor, and ciliary neurotrophic factor polymorphisms. Am J Clin Nutr. 2005; 82: 740-746.

8. Song Y, You NC, Hsu YH, et al. FTO polymorphisms are associated with obesity but not diabetes risk in postmenopausal women. Obesity (Silver Spring). 2008; 16(11): 2472-80. DOI: 10.1038/oby.2008.

9. Phani NM, Vohra M, Rajesh S, et al. Implications of critical PPAR $\gamma 2$, ADIPOQ and FTO gene polymorphisms in type 2 diabetes and obesitymediated susceptibility to type 2 diabetes in an Indian population. Mol Genet Genomics. 2016; 291(1): 193-204. DOI: 10.1007/s00438015-1097-4.

10. Frayling TM, Timpson NJ, Weedon MN, et al. A common variant in the FTO gene is associated with body mass index and predisposes to childhood and adult obesity. Science. 2007; 316: 889-894. DOI: 10.1126/ science. 1141634

11. Kang Y, Liu F, Liu Y. Is FTO gene variant related to cancer risk independently of adiposity? An updated meta-analysis of 129,467 cases and 290,633 controls. Oncotarget. 2017; 8(31): 50987-50996. DOI: 10.18632/oncotarget.16446.

12. Mutombo PB, Yamasaki M, Hamano T, et al. MC4R rs17782313 gene polymorphism was associated with glycated hemoglobin independently of its effect on BMI in Japanese: the Shimane COHRE study. Endocr Res. 2014; 39(3): 115-9. DOI: 10.3109/07435800.2013.844163.

13. Leońska-Duniec A, Jastrzębski Z, Zarębska A, et al. Impact of the Polymorphism Near MC4R (rs17782313) on Obesity- and MetabolicRelated Traits in Women Participating in an Aerobic Training Program. J Hum Kinet. 2017; 58: 111-119. DOI: 10.1515/hukin-2017-0073.

14. Statistical Yearbook. Zachodniopomorskie Voivodship 2015. Statistical Office in Szczecin

15. Szkup M, Owczarek AJ, Schneider-Matyka D, Brodowski J, Łój B, Grochans E. The fat mass of the peroxisome proliferator-activated receptor gamma (PPAR- $\gamma$ ) and obesity-associated (FTO), and the melanocortin-4 receptor (MC4R) genes. Aging (Albany NY). 2018; 10(1): 72-82. DOI: 10.18632/aging.101360.

16. Szkup M, Brodowski J, Owczarek AJ, Choręza P, Jurczak A, Grochans E. Searching for factors raising the incidence of metabolic syndrome among 45-60-year-old women. Aging Dis. 2018; 9(5): 831-842. DOI: 10.14336/AD.2017.1027

17. Alberti KG, Eckel RH, Grundy SM, et al. Harmonizing the metabolic syndrome: a joint interim statement of the International Diabetes Federation Task Force on Epidemiology and Prevention; National Heart, Lung, and Blood Institute; American Heart Association World Heart Federation; International Atherosclerosis Society; and International Association for the Study of Obesity. Circulation. 2009; 120(16): 1640-5.

18. Miller S, Dykes D, Plesky H. A simple salting out procedure for extracting DNA from human nucleated cells. Nucl. Acids Res. 1988; 16: 1215. DOI: $10.1093 /$ nar/16.3.1215.
19. Dytfeld J, Horst-Sikorska W. Znaczenie receptorów aktywowanych proliferatorami peroksysomów $\gamma(\operatorname{PPAR} \gamma)$ w fizjologii i patologii człowieka. [Peroxisomal proliferator-activated receptors $\gamma$ (PPAR $\gamma$ ) in human physiology and pathology]. Przegl Kardiodiabetol. 2009; 4: 187-191. In Polish.

20. Cecil JE, Fischer B, Doney AS, et al. The Pro12Ala and C-681G variants of the PPARG locus are associated with opposing growth phenotypes in young schoolchildren. Diabetologia. 2005; 48: 1496-1502. DOI: 10.1007/s00125-005-1817-0.

21. Cole SA, Mitchell BD, Hsueh WC, et al. The Prol2Ala variant of peroxisome proliferator-activated receptor-gamma2 (PPAR-gamma2) is associated with measures of obesity in Mexican Americans. Int Obes Relat Metab Disord. 2000; 24(4): 522-4.

22. Swarbrick MM, Chapman CM, McQuillan BM, et al. Pro12Ala polymorphism in the human peroxisome proliferator activated receptor gamma 2 associated with combined hyperlipidaemia in obesity. Eur J Endocrinol. 2001; 144: 277-282.

23. Altshuler D, Hirschhorn JN, Klannemark M, et al. The common PPARgamma Pro12Ala polymorphism is associated with decreased risk of type 2 diabetes. Nat Genet. 2000; 26: 76-80. DOI: 10.1038/79216.

24. Sanghera DK, Demirci FY, Been L, et al. PPARG and ADIPOQ gene polymorphisms increase type 2 diabetes mellitus risk in Asian Indian Sikhs: Pro12Ala still remains as the strongest predictor. Metabolism. 2010; 59(4): 492-501. DOI: 10.1016/j.metabol.2009.07.043.

25. Qi Q, Kilpeläinen TO, Downer MK, et al. FTO genetic variants, dietary intake and body mass index: insights from 177330 individuals. Hum Mol Genet. 2014; 23(25): 6961-6972. DOI: 10.1093/hmg/ddu411.

26. Zeggini E, Weedon MN, Lindgren CM, et al. Replication of genomewide association signals in UK samples reveals risk loci for type 2 diabetes. Science. 2007; 316: 1336-1341. DOI: 10.1126/science.1142364.

27. Li H, Wu Y, Loos RJ, et al. Variants in FTO gene are not associated with obesity in a Chinese Han population. Diabetes. 2007; 57: 264-268. DOI: $10.2337 / \mathrm{db} 07-1130$.

28. Ohashi J, Naka I, Kimura R, et al. FTO polymorphisms in oceanic populations. J Hum Genet 2007; 52: 1031-1035. DOI: 10.1007/s10038007-0198-2.

29. Binh TQ, Phuong PT, Nhung BT, et al. Association of the common FTO-rs9939609 polymorphism with type 2 diabetes, independent of obesity-related traits in a Vietnamese population. Gene. 2013; 513(1): 31-5. DOI: 10.1016/j.gene.2012.10.082.

30. Wang T, Ma X, Peng D, et al. Effects of Obesity Related Genetic Variations on Visceral and Subcutaneous Fat Distribution in a Chinese Population. Sci Rep. 2016; 6: 20691. DOI: 10.1038/srep20691.

31. Qi L, Kraft P, Hunter DJ, et al. The common obesity variant near MC4R gene is associated with higher intakes of total energy and dietary fat, weight change and diabetes risk in women. Hum Mol Genet. 2008; 17(22): 3502-3408. DOI: $10.1093 / \mathrm{hmg} / \mathrm{ddn} 242$.

32. Loos RJ, Lindgren CM, Li S, et al. Common variants near MC4R are associated with fat mass, weight and risk of obesity. Nat Genet. 2008; 40(6): 768-775. DOI: $10.1038 /$ ng.140. 